\title{
確定給付型企業年金におけるモラル・ ハザードと受給権保護
}

\section{李洪茂}

\section{ロアブストラクト}

確定給付型企業年金の受給権保護には，次のような問題点がある。第一に， 加入者期間中に受給権の付与 (vesting) が行われておらず，積立不足の解 消が困難な場合等は, 加入者拠出分を含めて, 受給者及び加入者の両方の減 額が認められたことによって，積立不足を拡大させて減額を行う企業のモう ル・ハザードが誘発されている。第二に，独立性のない年金数理人が積立義 務の履行状況を確認しており，年金業務に対寸る監督権が厚生労働省・国税 庁・金融庁に分割されたことによって，受託会社の営業活動などに対する監 督が不十分となり, 積立義務の回避または減額のための積立不足の水増し等 の企業のモラル・ハザードを高めている。第三に，支払保証制度がないため， 企業のモラル・ハザードの多くが各年金基金別に放置され，管理されていな い。受給権保護のための確定給付型企業年金の一体的な監督と企業のモう ル・ハザードの防止のための抜本的な改革が急がれている。

\section{ロキーワード}

確定給付企業年金, 受給権, モラル・ハザード

\section{I . 問題の所在}

日本の企業年金は，伝統的に，確定給付型企業年金しか存在していなかっ *平成19年10月27日の日本保険学会大会（桃山学院大学）報告による。 / 平成 20 年 9 月 22 日原稿受領。 
確定給付型企業年金におけるモラル・ハザードと受給権保護

た。この確定給付型企業年金における受給権とは，年金制度の規定に基づい て算出された発生給付額を将来受け取る権利のことを意味するが，加入者と 受給者は，将来にそれを受取れなくなる信用リスク (Credit Risk) 負って いるため，受給権の保護が必要となる。従って，確定給付型企業年金をリス クという観点からみれば，加入者・受給者と企業は，利益相反関係におかれ ている。この確定給付型企業年金では，企業がその支払責任を負っており， 年金数理による予測（見積もり）に基づいてその財政が管理されるが，企業 にその支払責任があるため，企業にそのリスクが集中する仕組みであること が問題とされた。

この確定給付型企業年金における企業のリスクを加入者に転換するものと して ${ }^{1)} ， 1990$ 年代のバブル崩壊以降に悪化した経営環境を背景にして，2001 年10月に施行された確定拠出年金法によって，確定拠出年金が実施された。 この確定拠出年金は，企業の支払い責任を掛金の払い込みに限定して，掛金 が加入者個人の口座に払い込まれ，その後は加入者の責任となる仕組みであ る。従って，確定拠出年金は，難解な年金数理による予測を必要とせず，企 業のモラル・ハザードの可能性も殆どない簡潔なものであるといえるが，確 定給付型企業年金における企業のリスクを加入者に転換したものであるとも いえる。

一方，既存の確定給付型企業年金である適格退職年金・自社年金などには 積立義務がないなどの受給権保護に問題があるとされ，受給権保護を目的と して，2002年 4 月 1 日に確定給付企業年金法が施行された。この確定給付企 業年金法は，厚生労働大臣の認可を受ける確定給付企業年金に適用されるも のであり，厚生労働大臣の認可を受けていない適格退職年金・自社年金には 適用されない。この確定給付企業年金法の網羅性のない選択的な適用は，同 法が受給権保護を目的としているにも拘らず，既存の企業年金の受給権を著

1）確定給付型企業年金では，転職等の際には既存の年金制度から脱退されるた め，通算制度を意味するポータビリティ（portability）がないことも問題とさ れた。 
しく悪化させる原因にもなっている2)。

さらに，確定給付企業年金は，そのリスクが企業に集中するものであるが， 企業のリスクを限定的なものにする目的で，キャッシュバランス・プラン (Cash Balance Plan) が認められた。これは，確定給付企業年金法では確 定給付企業年金の一種として扱われているが，加入から支給終了までのすべ ての期間にわたって指標利率（国債利回り等に連動）によって給付額が変わ る設計をも可能にすることによって，企業のリスクを一定範囲に制限したも のである。

その結果，確定給付型企業年金（Defined Benefit Plan）には，適格退 職年金・厚生年金基金・自社年金・確定給付企業年金（キャッシュバランス・ プランを含む）が混在することになった。これらは，いずれも本質的には退 職給付の一種という同じ性質の制度であり，同一の原理の年金数理が適用さ れるが，その適用法律と監督官庁が異なることから，その名称を異にしてい るだけである。この複雑な状況を利用して，年金数理不正が行われる状況と なった ${ }^{3)}$ 。また，適格退職年金は，2012年 3 月までに廃止されるため，企業 の掛金の損金算入のためには，積立不足を給付の減額などの方法によって解 消するなどして，新企業年金制度に移行する必要がある。

このように，企業年金は，近年，主に企業のリスクを軽減し，その選択肢 を増やすために大きく変化した。企業のリスク軽減と選択肢の増加は, 加入 者・受給者と企業が利益相反関係にある中で, 企業のモラル・八ザード

2）拙稿「確定給付企業年金における受給権保護とその実効性」『早稲田商学』 第409・410合併号，早稲田商学同攻会，2006年12月。

3）早稲田大学年金（自社年金）では，適格退職年金と確定給付企業年金などに おける責任準備金の定義が異なることを利用した住友信託銀行作成のシミュレ ーションによって，年金規則に規定された掛金の一部を積立不足に含める方法 で，積立不足を水増しし，その積立不足を基準に減額した年金数理不正が発覚 している。詳細については, 早稲田大学教員組合『企業年金改革という名の積 立不足転嫁術』年金問題調查委員会・情報宣伝部，2005年 ; 「早稲田大学の年金 を知る会」のホームページ (http://nenkin.earth.edu.waseda.ac.jp/) 参照。 
確定給付型企業年金におけるモラル・ハザードと受給権保護

(Moral Hazard $)^{4)}$ を誘発して受給権を阻害する可能性を秘めているもので もある。しかし，確定給付型企業年金の給付額は，退職時の最終的な給与額 と勤続年数に比例する金額となっているため，従業員の立場からみれば，退 職までのインフレーションなどへの対応に優れた面を有している。従って， 確定給付型企業年金は，高齢化が急速に進展している中で，企業年金として 一定の役割を果たしていくとみられる。

一方，確定給付型企業年金のリスクに関する研究は，主に，企業の立場か らのもので，加入者および受給者の立場からのものはあまり見当ならない5)。 本稿では，確定給付企業年金を中心として，受給権保護に必要される「受給 権の付与・積立義務・支払保証」の観点から，確定給付型企業年金における 企業のモラル・ハザードの可能性とそれの受給権保護への影響を分析し，そ の対応の方向性を提示することとする。

\section{II. 受給権の付与と減額}

日本の企業年金は，その多くが退職金を年金化したものである。この退職 金の経済的性質としては，長期の勤続に対する「功労報償」，賃金の一部の 支払いを退職時に繰り延べる「賃金の後払い」「老後の生活保障」，の3つ

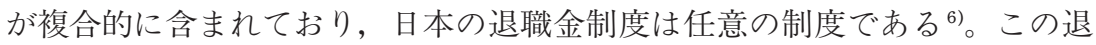
職金は，行政解釈（昭和22年 9 月13日発基17号）によれば，労働協約・就業 規則・労働契約等によってあらかじめ支給条件が明確に定められていれば使 用者にはその支給義務が生じるとされており，最高裁もこれを確認する判断

4）拙稿「保険料」『保険論』成文堂，2007年，pp.98-99。

5）加入者・受給者の立場からの経済学的な分析としては，石田成則『老後所得 保障の経済分析年金システムの役割と課題』東洋経済新報社（2007年10月）が 詳しい。

6）韓国の勤労基準法第34条 1 項には，使用者は，勤続年数 1 年につき，30日分 以上の平均賃金を退職者に支払わなければならないと規定されている。退職金 を法定化した国として，韓国の他に，台湾が知られている。 
を示している7)。従って，就業規則等で支給基準が定められている退職金は， 労働基準法上の賃金に該当し，同法の保護を受けている。この退職金の受給 権は，退職時に初めて成立するものと解釈されている（退職時成立説）。ま た，懲戒解雇に伴う退職金・企業年金の減額・不支給も可能になっており， 労働協約による不利益変更については，原則，可能とされている。

日本に扔ける企業年金は，退職金規定にその根拠が規定され，退職金の一 部または全部を企業年金に移行していることが多く，年金制度を廃止して， 退職金制度に戻れるものである。それによって，退職金と独立した企業年金 の受給権の概念の成立が難しくなっていると見られる。しかし，企業年金か ら支払われる年金や一時金は，退職金とは異なり，労働基準法上の使用者に よって支払われる貨金には該当しないとされ8)，それぞれの法制により保護 されている。つまり，退職金を年金化して確定給付企業年金の認可を受けれ ば，労働基準法ではなく，確定給付企業年金法が適用される。

一方，確定給付企業年金法における受給権すなわち「受給を受ける権利」 は，その権利を有する者の請求に基づき事業主等が裁定すると規定されてい る（法第30条) 9)。つまり，確定給付企業年金法の受給権では，退職金の性 格が引きずられており，在職期間中には受給権が与えられず，退職した後の 裁定によって，受給待期者を経て，またはすぐに受給者となるときに受給権 が確定されると考えられる ${ }^{10)}$ 。

さらに，確定給付企業年金では，退職金と同様，苆盗・横領などによる加

7） 最三小判昭和 43 年 3 月 12 日，小倉電話局事件，民集 22 巻 3 号562頁。

8）二ッセイ基礎研究所「年金法制受給権付与ルールの法制化に向けて (2)」『年 金ストラテジー』Vol.27，1998年 9 月。

9）確定給付企業年金法第30条は，すでに受給権が存在することを前提にしてい るとも解釈される（島崎謙治「企業年金の社会保障政策上の位置づけと受給権 保護」『PIE/CIS Discussion Paper』No.330, 一橋大学 経済研究所, 2007 年 9 月, pp.11-12)。

10）古市峰子『年金基金を巡る法律関係と会計処理との整合性について』Discussion Paper No. 99-J-9，日本銀行金融研究所，1999年 4 月，pp.3-12。 
確定給付型企業年金におけるモラル・ハザードと受給権保護

入者等の責めに帰すべき重大な理由によって実施事業所に使用されなくなっ た場合は，給付の一部または全部を没収することができる（施行令第34条第 2 号)。また，中途採用などにより定年までに予測される加入者期間が 20 年 に満なない場合には, 加入者としないことは可能であり, 一旦加入者となっ た者に対しても20年を超えない加入者期間を老龄給付金の受給要件として設 定することができる (法第36条) ${ }^{11)}$ 。つまり，加入者期間が20年に満たない 場合には受給権を与えないことができるのである ${ }^{12) 。 ~}$

また，確定給付企業年金法では，経営状況の悪化・掛金の大幅上昇などの 理由と, 加入者又は受給者の 3 分の 2 以上の同意・受給権者の場合は希望者 には一時金の支給などの手続きという一定の要件を満たすことを前提に，受 給者と加入者の両方に対する過去の加入者期間を含めた減額が認められてい る ${ }^{13)}$ 。さらに，確定給付企業年金では，加入者拠出を認めているが（法第55 条 2 項, 令第 35 条), この加入者拠出分までもが過去の加入者期間を含めて 減額の対象とされる。確定給付型企業年金では原則的に減額は認められなか ったが，厚生年金基金において，年金財政破綻の増加を受けて，1997年度よ り「基金存続のために，真にやむを得ない」場合には，受給者の給付の引き 下げも可能になったことが引き継がれたものである。厚生年金基金，確定給 付企業年金，適格退職年金（自主審査要領）に，同様の減額規定が設けられ たため，企業の自社年金でも援用されることが考えられる。

また，2001年からは新たな退職給付会計が導入され，多くの企業で企業年 金の積立不足が表面化した。それまでの従来の適格退職年金では，積立義務 もなく，積立不足などがあっても貸借対照表に記載していなかったが，退職

11） 2001年に導入された確定拠出年金では, 受給権が加入後 3 年で確定し, 懲戒 解雇されても減額・不支給にはできなくなった。

12）加入者が中途退職などによって規約で定める老齢年金の受給要件を満なさな くなった場合， 3 年を超えない加入者期間を定め，脱退一時金を支払うことが できる。

13）減額の理由と手続きは, 確定給付企業年金法施行令第 4 条, 同施行規則第 5 条，第 6 条に規定されている。 
給付会計によって，その積立不足を負債として記載されるようになった。そ の負債が，株価や格付けなどの企業の評価に悪影響を与え，資金調達コス卜 の増加となることが懸念された。また，退職給付費用が損益計算書に計上さ れることにより，退職給付のコストが掛け金拠出分に限られないことが明ら かになり，企業は，退職給付費用を賃金と同じく人件費（労務コスト）の一 部として認識するようになったために，NTT・早稲田大学の年金訴訟など で見られるように，積立不足の解消とコストの節約のための年金額の減額の 動きが現れた。つまり，企業の経営が悪化した場合または積立不足が大きな ってそれを解消するための掛金（特別掛金）の負担が困難となった場合など では，確定給付型企業年金の積立不足の解消方法として減額が認められ，こ の減額は，将来的に継続的な企業のコスト節約方法としてとても魅力的な方 法として見られるようになったのである。その結果，積立不足を放置または 拡大させ，ときには年金数理などの不正な方法で積立不足を水増しして，経 営困難と企業の負担できない膨大な積立不足を理由に減額を行う場合がみら れ，積立不足の負担を加入者と受給者に転嫁しようとするモラル・ハザード が誘発されている ${ }^{14)}$

一方，アメリカでは，1974年に制定されたERISA (Employees Retirement Income Security Act of 1974) ${ }^{15)}$ によって，加入者期間中に，受給 権の付与 (Vesting) が行われている。ERISA では，企業年金制度を使用 者が創設すること自体は求めていないが，いったん制度を創設すると規制を 受けることになる。その受給権の付与は，2006年年金保護法 (Pension

14）早稲田大学年金（自社年金）では，積立不足の水増しまたは過大評価による 減額が行われた（詳細な内容は，早稲田大学教員組合『前掲書』; 「早稲田大学 の年金を知る会」のホームページ参照)。

15） ERISAには，(1)加入員や行政に対する情報開示，(2)制度への加入資格や受 給権付与の最低基準，(3)年金資産の最低積立基準の設定，(4)制度の管理・運営 者の受託者責任，(5制度終了保険，などが規定されている。 
確定給付型企業年金におけるモラル・ハザードと受給権保護

Protection Act of 2006) ${ }^{16)}$ にって, 次のようにさらに強化された ${ }^{17)}$ 。

加入者が 3 年勤務した時点で100\%の受給権が付与される（three-year cliff vesting)。(2加入者が 2 年勤務した時点で $20 \%$ ，それ以降 1 年毎に $20 \%$ ずつ 上乗せする方法して，6 年勤務した時点で100\%の受給権が付与される (two-to-six-year phased vesting)。また, 加入者拠出は, いつも100\%受 給権が与えられる。一度付与された受給権は, 労働者の中途退職，または不 正行為を理由に解雇された場合でも使用者が没収することは許されていない が，将来分の減額については制限がない18)。

また，イギリスでは，公的年金の二階の部分が被用者年金である国家第二 年金（S2P：State Second Pension）であるが，「適用除外制度（contract out）」によって, 企業年金に加入すれば脱退でき，さらに保険会社から適格 要件を満たす個人年金またはステークホルダー年金 (Stakeholder Pension Plan）を購入した場合でも脱退できるものである。1986年社会保障法（the Social Security Act of 1986) と1986年租税改革法（The Tax Reform Act of 1986）によって，最低受給権付与期間（minimum vesting time） が 5 年から 2 年に短縮され，企業年金では，2 年以内に受給権を付与するよ うになった。一旦与えられた受給権の没収はできない19)。早期退職者に対し て受給権が与えられた確定給付企業年金は，後払い年金（deferred bene-

16） 2006年年金保護法によって，内国税法 (Internal Revenue Code) と ERISA (Employee Retirement Income Security Act of 1974) の年金に関 する規定が大幅に修正された。

17） ERISA 203条(b)には，次の何れかの方法で受給権を与えることが規定され ていた。(1)加入者が 5 年勤務した時点で $100 \%$ の受給権が付与される。(2)加入 者が 3 年勤務した時点で $20 \%$ ，それ以降 1 年毎に $20 \%$ ずつ上乗せして， 7 年勤 務した時点で100\%の受給権が付与される。

18） 1980年代には将来の分の年金額の削減のための「譲歩交渉（Concession Bargaining)」が通例となった。

19) E. Philip Davis, Regulation of Private Pensions - A Case Study of the UK, DISCUSSION PAPER PI-0009, The Pensions Institute Birkbeck College, University of London, October 2000. 
fits）としてその権利が保存され，5\%を限度とした消費者物価指数に連動 して再評価することによって，確定給付企業年金の長所が維持されている ${ }^{20)}$

\section{III．積立義務と受給権保護}

\section{1 ．年金財政と積立義務}

積立義務は，確定給付企業年金法で実現された唯一の受給権保護の手段で あるが21)，掛金の払い込みと資産運用によって行われる。確定給付企業年金 や厚生年金基金では，少なくとも5 年に一度は定期的に，将来に向けた掛金 の見直しである財政再計算が行われる（法第58条)。財政再計算は，基金の 財政状況，設立母体の状況，経済・金融情勢等の変動を適宜反映し，計算基 礎率等の前提条件（基礎率）の見直し等を通じて掛金率を設定し，年金財政 を点検するものである。経済状況が変動せずに前提条件の通り推移する場合 には，財政再計算で計算した掛金を負担すれば，将来の給付に見合う年金財 政が維持できる。しかし，現実の世界で，財政再計算で前提された前提条件 が，その通りに実現されるとは限らない。従って，確定給付企業年金法では， 事業主などは，財政再計算とは別に，毎事業年度の決算において，積立金が 責任準備金と最低積立基準額を上回っているかどうかの財政検証を行うこと が求められている (法第61条)。

財政検証とは，毎年の事業年度末に行われる積立目標額による積立金との 比較であるが，継続基準と，非継続基準による二つの観点から行われる。継 続基準では，継続企業（going concern）を前提にして，現在の加入者と受 給者が退職した後に発生する給付を前提とした将来の給付が行えるように， 積立目標として「責任準備金」が設けられる ${ }^{22)}$ 。実際の年金資産が責任準備

20) Vincenzo Andrietti, Pension Choices and Job Mobility in the UK., 2002 , p. 5 .

21）受託者責任と情報開示も受給権保護の手段として説明されているが，企業の モラル・ハザードの防止のための手段であり，受給権保護の補助的な手段と理 解すべきであろう。

22）ここでの責任準備金とは，数理債務（負債勘定）から特別掛金収入現価（資 
確定給付型企業年金におけるモラル・ハザードと受給権保護

金と同額であれば，将来の給付は，保有する年金資産とその運用収益，将来 の標準掛金，特別掛金で賄える見込みであることを示している。一方，年金 資産が責任準備金を下回っていれば，将来の給付を賄うのに十分な積立水準 ではないことになる。

また，非継続基準 ${ }^{23)}$ では，最低保全給付のための最低積立基準額が積立目 標として設けられる。この最低積立基準額は「最低保全給付の現価相当額の 合計額」であり，最低保全給付とは，決算日現在で，厚生年金基金または確 定給付企業年金が解散・制度終了したと仮定した場合，その時点までの加入 期間に応じて発生したとみなされる給付であるが，加入者・受給者・受給待 期者の受給権確保の観点から導入された概念であるとされる。しかし，前述 した通り，加入者期間中には受給権が与えられないので，この年金基金の全 体的な積立金が個別の受給権として具体化されてはいない。確定給付企業年 金法では，非継続基準による最低積立基準額を基準に，その積立不足を基準 に計算した金額を掛金として拠出することが求められている（法63条，施行 規則第58条，59条）。従って，確定給付企業年金法における積立義務とは, 年金制度の解散などによる終了を前提とした最低積立基準額の積立義務であ るといえる。

この最低積立基準額が受給権保護に適した基準であるのかは，それぞれの 企業の授業員の年歯構成と受給条件にもよる。日本の退職給付は, 一般的に $\mathrm{S}$ 字曲線を描いており，一定の勤続年数になったときに，給付が急速に増加 する構造であり，また受給資格を 20 年以上と定める場合も多いため ${ }^{24)}$, 評価 時点で退職すると仮定した場合の最低積立基準額が責任準備金よりも少なく

産勘定）を控除した金額である。数理債務は，当該事業年度の末日における給 付に要する額の予想額の現価から標準掛金額の予想額の現価を控除した額であ る。

23）坪野剛司『新企業年金』日本経済新聞社，2005年 4 月，pp.76-78。

24）確定給付企業年金では，2006年 9 月現在，加入者要件については，「加入期 間20年以上」とする企業が70.8\%であった（労務行政研究所『2007版退職金・ 年金事情』労務行政, 2007年 4 月, p.149)。 
なる場合も想定されるからである。従って，非継続基準による積立基準は満 たしていても継続基準による積立基準は満たしていない場合も予想される ${ }^{25)}$ また，年金制度の終了時に積立額が最低積立基準額を下回るときは，事業 主は，当該下回る額を，掛金として一括して拠出しなければならない（法第 87条)。この制度終了の際に，残余財産は加入者等に分配し，事業主への返 還は認めない (法第89条)。制度の終了の際の一括拠出は，任意終了の場合 は確かに効果があるとみられる。しかし，企業の倒産などの際には，強制徵 収などの措置がないために，企業の一括拠出の履行を期待することは難しく，

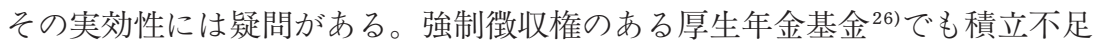

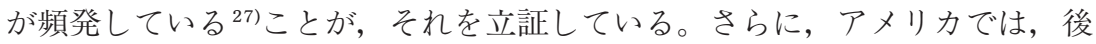
述するように，厳しい積立義務を課し，積立不足に対する先取特権を認めて も，積立不足が頻発している事例がそれを証明している。

また，確定給付型企業年金は，確定拠出企業年金とは異なり，年金数理を 必要としているが，確定給付企業年金法の積立義務は，年金数理人制度によ って維持することが期待されている (法第97条)。厚生労働大臣が認定する 年金数理人は，その殆どが信託銀行などの受託会社の社員でもあるが，受託 会社は手数料収入を目的に熾烈な年金基金の受け入れ競争を繰り広げており， 年金財政の決算書と減額などの制度変更の判断資料となるシミュレーション をも作成して制度変更などの提案を行っている。これら受託会社の社員とし

25） ERISAの前では，退職時に一括して積み立てるなどの賦課方式であったた めに，積立不足の問題が多かった。1974年に ERISA に導入された確定給付企 業年金の積立基準は，PBO（Projected Benefit Obligation）基準であった。 当時としては製造部門と運送部分の労働者の年齢が若かったので，企業は掛金 を低く抑えることになった。

26）厚生年金基金では，掛金については，公的年金との関係で，国税滞納処分に 準じた強制徴収権がある (厚生年金保険法第86-87条)。しかし，確定給付企業 年金法には同様の規定はなく，法令に違反した場合の改善命令の規定などがあ る。

27）厚生年金基金の支払保証事業の支払い件数は，厚生労働省によると，2005年 度1,472件，2006年度に 1,067 件である。 
確定給付型企業年金におけるモラル・ハザードと受給権保護

ての独立性のない年金数理人は，企業が委託者（規約型）となるなめ，企業 の代理人といえるが，確定給付企業年金法では，リスクの面において企業と 利益相反関係にある加入者と受給者のための積立義務の履行状況などの数理 業務の確認者とされている。このような状況下で，年金数理人は，企業に有 利な数理不正を行うことによって，受給権を阻害せざるを得なくなる場合が あることは，容易に予測されることである ${ }^{28)}$ 。

この年金数理人は厚生労働大臣によって指定されるが，受託会社の営業活 動などは金融庁の監督下におかれている監督権の分割のため, 確定給付型企 業年金の監督が一体的に行われておらず，企業年金の受託のために不正な年 金数理を使って行われる営業などに対する監督は十分に行われていない。ま た，日本年金数理人会によれば，適格退職年金と自社年金は，年金数理人の 業務外とされている。しかし，己れらの企業年金の数理は，他の確定給付型 企業年金と同じ原理であるため，年金数理人が担当しているのが実情である。 このような状況では，確定給付型企業年金の積立目標額の算出・財政検証お よびその履行が適正に行われているかを確認することは難しく, 確定給付企 業年金の積立義務における企業のモラル・ハザードの発生可能性は高い。

\section{2.資産運用}

確定給付型企業年金は，年金額が算式によって決まっている給付建てであ るため, 予定利率よりも高い資産運用収益が発生した場合，その超過収益は 企業の持分となり，年金額が増額されることはない仕組みである。この仕組 みが企業の行動に影響を及ぼしてきた良い事例は，厚生年金基金である。厚 生年金基金は，公的年金部分である厚生年金保険の一部を国に代わって運 用・給付等の代行を行い，それに加えて企業独自の上乗せ給付（プラスアル

28）「早稲田大学の年金を知る会」は，年金数理不正を理由として，日本年金数 理人会（2006年 6 月 6 日）と日本アクチュアリー会（2006年 7 月 14 日）に対し て, 住友信託銀行所属の年金数理人の除名申し立てを行っている（「早稲田大 学の年金を知る会」のホームページ)。 
ファ）を行うものである。この厚生年金部分は，公的年金として国が決めた 金額のみを支払うものであるため，その運用による超過収益をプラスアルフ アに回して企業年金の一部とすることができた。しかし，公的年金の予定利 率（1989年から1999年まで5.5\%）は，長期の予測であるという理由で，当 時としては市中金利に比べると低く抑えられたものであるため，その代行部 分の資産運用による超過収益は，将来の低い運用収益のときのために，公的 年金の積立金として積み立てられるべきものであった。

しかし，1990年代になると，資産運用環境が悪化して，公的年金の予定利 率を下回る運用利回りになり，その不足分が積立不足の増加の要因となった。 さらに，前述した退職給付会計の導入によって，厚生年金基金の代行部分の 積立不足までが負債（積立不足）として貸借対照表に計上されるようになっ たが，厚生年金基金が代行部分を国に返上してなくすためには，解散しか方 法がなかった。これに対応するため，確定給付企業年金法では，代行部分の みを国に返上してプラスアルファのみを残すことによって，確定給付企業年 金（規約型または基金型）への移行が認められた。つまり，厚生年金基金の 代行部分から超過利潤がなくなると, 過去の超過収益の返還義務なしに, 積 立金を国に返還して，代行を終了することが認められた。このような状況は， 企業年金と厚生年金の調整という過去の経緯があるにしても，強制加入の公 的年金である厚生年金の予定利率を超える運用収益を，厚生年金基金を創設 した企業に限定して補助金として支援したといえ，企業のモラル・八ザード を引き起こした事例である。

一方，確定給付型年金では，実際の運用収益が予定利率に満たない場合は 企業が補てんすることを原則とするが，それを超える収益は，企業に帰属す る仕組みであるため，企業が高収益を狙った危険な資産運用をする場合が出 てくる制度の宿命的な問題がある。近年における規制緩和とともに，投機的 な運用によって資産運用に失敗した場合，年金財政の悪化を理由に減額を行 う事例が現れている ${ }^{29)}$ 。厚生年金基金などの年金資産運用におけるいわゆる 29）早稲田大学年金では，2000年から約 3 年間で，資産額の約 7 割を国内外の株 
確定給付型企業年金におけるモラル・八ザードと受給権保護

$\ulcorner 5 ： 3 ： 3 ： 2$ 規制」は, 安全性の高い資産 5 割以上, 株式 3 割以下, 外 貨建て資産 3 割以下，不動産等 2 割以下に制限する規制であったが，1997年 12月に撤廃されていた。これは，事実上，確定給付型企業年金の超過収益は 企業の持分としながらも，資産運用リスクを加入者・受給者に転嫁している ものであり，企業のモラル・ハザードを誘発しているものである。

\section{IV. 支払保証制度とモラル・ハザード}

確定給付型企業年金は，資産運用を企業の責任で行っているため，企業倒 産の際にはその積立金の確保が問題となる。ここで問題になるものが，支払

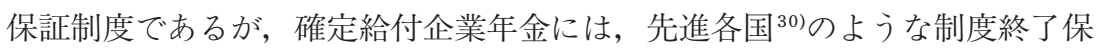

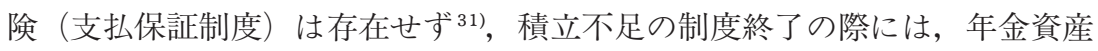
のみが給付の財源となる。確定給付企業年金法の制定時において，支払保証 制度については，検討課題の一つとされていたが，未だにその実現の目処は 立っていない。従って，企業の倒産などの際に積立不足が存在する場合は， 年金額の減額を余儀なくされる。

一方，アメリカの確定給付企業年金では ${ }^{32}$, PBGC (Pension Benefit

で運用し，約200億円の資産が約140億円へと約60億円の目減りが発生した後に， それを含む積立不足の解消を目的した減額が行われた。詳細な内容は,「早稲 田大学の年金を知る会」のホームページ参照。

30）アメリカ，カナダ，イギリス，ドイツ，スウェーデンなどに支払保証制度が ある（厚生労働省年金局「企業年金のリスク管理について」2007年 4 月27日，

p.28; Stewart, F., "Benefit Security Pension Fund Guarantee Schemes", OECD Working Papers on Insurance and Private Pensions, No.5, OECD Publishing, 2007)。

31）厚生年金基金には1988年に導入された支払保証事業があり，解散に至った厚 生年金基金の年金資産の積立額が保証限度額を下回っている場合に，解散基金 の加入員に一定の年金給付を保証する制度で，企業年金連合会が全厚生年金基 金の参加のもとに実施している共済事業である。

32）アメリカの企業年金には，単独雇用主企業年金 (single-employer pension plan) と複数雇用主企業年金（multiemployer pension plan）がある。複数 雇用主企業年金とは, 労働管理法 (Labor Management Relations Act of 
Guaranty Corporation；年金給付保証公社）により企業の倒産の際に年金 受給が保証される ${ }^{33)}$ 。アメリカの ERISAの第 4 章には，PBGC が規定され， 連邦の公的機関として設立されている ${ }^{34)}$ 。公務員または 26 人以下の専門職場 （医師または弁護士）を除けば，給付額が月額で特定できる確定給付型企業 年金の殆どが付保されている。その財源は，財政からの支援はなく，企業年 金プランからの保険料（保証料）とその運用益によって運営されている。保 証の対象は，企業倒産が生じたとき，その企業の年金資産が ABO（Accumulated Benefit Obligation；清算基準の年金債務）に満たなかったと きの積立不足である。また，PBGC は，倒産した企業の年金基金に積立不 足がある場合は，残余財産について先取特権を持ち，残余財産を処分しても 積立不足が埋まらなかったときに，その金額を保証する。

PGBC の設立当時では，年金ブランの終了の理由を問わず，年金ブラン の積立不足が保証された。そのため，企業は積立不足があれば PGBC が保 証してくれると考え，積立不足を十分に管理しようとしないモラル・ハザー ドが発生した。この問題を解決するため1980年代に年金プランの破たん防止 を行うようになり，母体企業の倒産などの理由によって年金フランを終了し た場合にのみ，年金給付の保証が行われるようになった。

PGBC では，モラル・ハザードの防止のために，次のような措置がとられ ている。第一に，差別的な保険料の賦課である。PGBCの保険料は二種類 に構成されている。一つは，企業年金プランの加入者一人当たりの定額保険

1947）によって規定されたものであるが，短期労働者が複数の雇用主から与え られたクレジットを累積して年金を受給するものである。

33）年度別に年齢別の月額で保証の限度額が設定される。2008年に終了した制度 に対する支給開始65歳の保証上限は，単生終身年金は月額 $\$ 4,312.50$, 連生年 金（遺族年金 $50 \%$ ）は月額 $\$ 3,881.25$ である（金額は社会保障課税賃金の基準 に連動して改定）（http://www.pbgc.gov）。

34）理事長（Director）は大統領が任命し，保証料は国会が設定する (http:// www.pbgc.gov)。 
確定給付型企業年金におけるモラル・ハザードと受給権保護

料 (flat premium rate) ${ }^{35)}$ であり，もう一つが清算基準の $\mathrm{ABO}$ 基準の積立 不足に比例して上限なしに大きくなる変額保険料（variable-rate premium）（積立不足 1,000 ドル当たり 9 ドル）である。この変額保険料によっ て企業に積立不足をなくすように促している。第二に，早期警告プログラム (Risk Mitigation Program (Early Warning Program)) の実施である。 PGBC は, 積立不足が大きい企業を抽出して ${ }^{36)}$, 当該企業が年金財政を悪 化させる経営活動（取引）を行う場合は，介入するものである。第三に，情 報開示の徹底である。ERISA は，企業が必要な掛金を払い込めなかった場 合は, 加入者に通知しており $(101$ 条 $(d))$, 加入者に送られる年次報告書には, 掛金の払い込み・積立の状況等が詳細に記録される。

イギリスにおいても，2004年年金法（the Pensions Act 2004）によって， 2005年 4 月に年金保護基金（Pension Protection Fund；PPF）を創設して， 確定給付企業年金を対象にした支払保証制度が導入された。年金保護基金は， すべての適格企業年金から強制的に徵収される保険料によって運営されるが， 保険料は，初年度は定率（flat-rate）であったが，2006年からは，その20 \%は制度の要因 (負債総額)，残りの $80 \%$ は年金保護基金の評価によるリス クによって，差別される変動率となった。年金保護基金における支払い不能 となった年金基金の加入者・受給者に対する補償金額は，次の通りである。 (1)定年年齢または疾病により退職した者，遺族年金者は，限度額（cap）な しで，年金額の $100 \%$ ，22その他の個人には，限度額の範囲内で，倒産時点 での年金額の $90 \%$ までを定年年齢に達した時に支払われるが，定年年歯まで はインフレーションにリンクして毎年 $5 \%$ を限度として増額される ${ }^{37)}$ 。

また，2004年年金法のいわゆる「モラル・ハザード規定（moral hazard

35） 2008 年の単独企業主プランの定額保険料は, 加入者一人当たり 33 ドルである (http://www.pbgc.gov/docs/2007_annual_report.pdf)。

36）企業の格付けが投資不適格で責任準備金（CL）が2,500万ドルを超える企業 の積立不足が500万ドルを超える場合に調査を始める。

37）例えば，65歳に退職した場合，2008年度の限度額の $90 \%$ 年額£ $27,770.72$ である。 
provisions）」は，年金監督官が雇用主に対して積立不足の全額を遅滞なく 支払うことを要求できるものであるが，最終的にPPFの負担となる雇用主 の意図的な年金債務の回避を防ぐためのものである。その内容は, Buy-out 基準 ${ }^{38)}$ での積立不足がなくなるまで掛金の支払いを要求する「掛金払込通知 書 (Contribution Notices；CNs)」と積立不足の効果的な保証（guarantee）要求する「財政支援指図書（Financial Support Directions; FSDs)」を発行する権限を与えたものである。さらに，PPFには，2004年 年金法によって，前の年金補償委員会 (Pensions Compensation Board) に代わり，2005年 9 月に不正補償基金（The Fraud Compensation

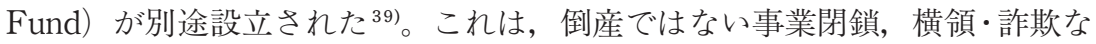
どを含む不正による積立不足が発生したときに補償するものである。

一方，日本では，企業の保証料負担と，それによる確定給付型企業年金の 確定拠出年金へのシフトに対する懸念と，確定給付型企業年金が，信託また は生命保険に限定されていることなどを背景にして，産業界と一部の受託会 社関係者などからは，支払保証制度の導入は必要ないという意見が多くみら れる。支払保証制度の創設に対して指摘されている主な問題点を要約すれば， 次の通りである ${ }^{40)}$ 。第一に，日本では，アメリカと異なり，年金額の減額が 認められている。また，日本における年金受給権は，曖昧で加入者期間中の 受給権付与も行われていないため，何を保証するかが明確ではない。第二に， 放漫経営をしている企業は，保証制度に頼って積立不足を放置するモラル・ ハザードの発生が予想される。また，企業年金の健全な運営を行っている企 業が，積立不足を増やして倒産した企業年金の積立不足の後始末をすること には納得が得られない。第三に，米国の年金制度では，PGBCが事業主に

38） Buy-out 基準とは，事業主が倒産していない状態で確定給付制度を終了さ せようとするとき給付を保証する年金商品を保険会社から購入するのに必要な コストで年金債務を評価することを意味する。

39） PPFのホームページ (http : //www.pensionprotectionfund.org.uk/)

40）厚生労働省年金局「企業年金のリスク管理について」2007年 4 月27日, p.18。 
確定給付型企業年金におけるモラル・ハザードと受給権保護

対して「累積拠出不足」相当額の先取特権（lien）を有し，拠出の猶予を認 める条件として担保（security）の提供が求められる場合がある。日本では， 厚生年金基金掛金に関して「国税および地方税に次ぐ先取特権」が与えられ ているが，確定給付企業年金に関しては，企業年金基金に一般債権がある， と解されるに過ぎない。

確かに，日本の労働基準法のもとでは，退職金の受給権が曖昧であり，懲 戒解雇の場合には年金の没収も可能であるため，確定給付企業年金にも同様 の規定が設けられたとみられる。しかし，確定給付企業年金には，労働基準 法が適用されるではなく，確定給付企業年金法が適用されるため，一度年金 化したものは退職金とは異なる性格を持っている。また，その確定給付企業 年金法には，保護すべきものとして，最低積立基準による最低保全給付が規 定されてあり，何を保護するかは明確にされている。それにもかかわらず， 確定給付企業年金法では，最低保全給付に対する受給権の付与が規定されて いないことが，保証すべき対象をあいまいにしているだけである。つまり， 退職金の性格が問題ではなく，確定給付企業年金法に受給権の付与規定がな いことが問題であるといえる。

また，企業の財政が悪化していたときに，掛金を払い込まず，または危険 な投資による運用損が発生したことによって，積立不足が大きくなってから 倒産した場合，積立不足のない企業が負担する保険料によって賄うことにな るモラル・ハザードの問題があるという議論は，もっとも古典的な議論であ る。しかし，いかなる保険制度にもモラル・ハザードは存在するものであ $\eta^{41)}$ ，企業年金のモラル・ハザードは，主として支払保証制度を創設するこ とによって生じるものではなく，すでに存在するものである。さらに，日本 の確定給付型企業年金のモラル・ハザードの多くは，その制度または監督体 制の問題によって誘発されていることは前述したとおりである。また，支払 保証制度は，すでに存在する企業のモラル・ハザード等の移転を受け，加入

41) Stewart, F., op.cit., p.6. 
者と受給者を保護する一種の信用保険である。従って，支払保証制度を創設 すればモラル・ハザードが発生するという主張は，企業と受託会社の利益の ため，加入者などに対する企業のモラル・ハザードを管理せずに各企業に放 置すべきという主張にもなる。

また，保険契約者は，安い保険料でより多くのリスクを移転させることを 望むことで逆選択が発生し，また危険移転後には保険を利用して利益を得よ うとするモラル・ハザードが発生することはよく知られていることである ${ }^{42)}$ しかし，保険制度では，モラル・ハザードを回避しながらその役割を拡大さ せてきており，諸外国で保険制度を利用して行われる支払保証制度において も，回避できている。その方法は，保険料の差別・情報の開示・監督官庁の 命令などであることは前述の通りである。

\section{V. 結び}

日本の確定給付型企業年金は，確定給付企業年金に一本化されつつあると はいえ，各省庁の選択的な監督が行われている問題がある。この確定給付型 企業年金における受給権保護には，次のような問題点がある。

第一に，確定給付基金年金で受給権の付与が規定されておらず，加入者拠 出分を含めて, 受給者及び過去の加入者期間に対する減額までが認められて いる。特に, 加入者に対しては受給権のない状態で減額が認められているこ とになる。これらは, 積立不足の解消と将来のコス卜削減のために減額しょ うとする企業のモラル・ハザードを誘発するものである。これは，受給権の 付与を強化している米英とは異なる動きである。第二に，積立義務は，非継 続基準（清算基準）による最低責任準備金の積立義務である。この積立義務 は，企業の倒産（清算）を前提にすれば，積立不足の解消のための強制徵収 などの措置がないため，その有効性に疑問がある。また，独立性のない年金 数理人が積立義務の履行状況を確認し, 受託会社の年金業務に対する監督が

42）拙稿「保険料」『前掲書』pp.98-99。 
確定給付型企業年金におけるモラル・ハザードと受給権保護

厚生労働省・国税庁・金融庁に分割されているため, その監督は十分に行わ れていない。退職給付としての確定給付型企業年金業務に関する一体的な監 督体制の整備が必要である。この各省庁による選択的な監督は，監督が疎か になる領域または分野を生じさせ，積立不足の不正な縮小による積立義務の 回避，または水増しを通じた減額の可能性，すなわち企業のモラル・ハザー ドの可能性を高めている。第三に，米英では，支払保証制度が，すべての確 定給付型企業年金を対象として，年金債務を回避しようとする企業のモラ ル・ハザードの移転を受け，それを管理することによって受給権を保護し， さらに積立不足が発生した場合には加入者・受給者の損害のてん補が行われ ている。しかし，日本では，このような支払保証制度は実施されておらず， 企業年金の廃止または減額を行う企業のモラル・ハザードは，各年金基金別 に放置され，管理されていない。

確定給付型企業年金における企業のモラル・ハザードは，経営を助けるた めに，確定給付型企業年金における企業のリスクを軽減して加入者・受給者 に転換するための減額規定を設ける過程で，さらに拡大された。その結果， 確定給付型企業年金の受給権が保護されず，加入者・受給者が負う信用リス クは大きくなった。受給権保護のための確定給付型企業年金の一体的な監督 と企業のモラル・ハザードの防止のための抜本的な改革が急がれている。

(筆者は早稲田大学教授) 